\title{
ANALISIS FAKTOR-FAKTOR MEMPENGARUHI KEPUASAN KERJA KARYAWAN PADA PT. ASTRA CABANG MEDAN
}

\author{
Betniar Purba \\ Universitas Katolik Santo Thomas Medan Jl. Setia Budi No. 479F, 20132, Indonesia \\ e-mail: betniarpurba20@gmail.com
}

\begin{abstract}
The purpose of this study is to analyze the factors that influence employee job satisfaction at PT Astra Medan Branch. The benefits of research help provide input to the leadership of the company in determining policies for the progress of PT Astra Medan Branch and can be used as reference material in enriching and deepening science. The number of samples was 105 respondents, the types of data used were primary and secondary data, and the method of data collection through questionnaires and documentation, the method of data analysis used factor analysis. The results showed that the KMO Measure of Sampling Adequacy (MSA) figure of 0.825 was above 0.50, with a significance of 0,000, so the variables were worthy of further analysis. Scree plot shows the graph, where from factor 1 to factor 2 (source line component number $=1$ to 2), the direction of the line decreases sharply. Then from number 2 to number 6 , the direction of the line is still decreasing with slope getting smaller. The seventh to twenty-first factors are below the number of the $Y$ axis (eigenvalues). This shows that the six factors are best for summarizing the twenty-one factors that influence employee job satisfaction at PT Astra Medan Branch. The dominant factors affecting job satisfaction of employees of PT Astra Medan Branch are incentives or bonuses, work policies and procedures, promotion of positions, intrinsic of work, social security and official vehicles. The most dominant factor influencing employee job satisfaction is incentives or bonuses. Suggestions that are recommended to company leaders should the company increase the amount of incentives or bonuses, pay attention to the establishment of work policies and procedures, maintain the provision of social security and official vehicles. The company should provide the greatest opportunities foremployees with the best performance to be promoted to higher positions.

Keyword: Employee job satisfaction factors
\end{abstract}

\section{PENDAHULUAN}

Kepuasan kerja karyawan merupakan cara pandang seseorang baik yang bersifat positif maupun negatif tentang pekerjaannya. Kepuasan atau ketidakpuasan bersifat subjektif merupakan hasil perbandingan antara apa yang secara nyata diterima oleh karyawan dengan yang diharapkan.

Menurut Robbins (2013: 91), “istilah kepuasan kerja merujuk pada sikap seseorang terhadap pekerjaan yang dilakukannya. Seseorang dengan tingkat kepuasan kerja tinggi, menunjukkan sikap positif terhadap pekerjaan itu; seseorang yang tidak puas dengan pekerjaannya menunjukkan sikap negatif terhadap pekerjaan tersebut. Dengan demikian, kepuasan kerja menunjukkan sejauh mana karyawan merasakan secara positif atau negatif berbagai macam faktor atau dimensi dari tugas-tugas dalam pekerjaannya. Gejala yang timbul akibat ketidakpuasan kerja karyawan adalah adanya keluhan, prestasi kerja mengalami penurunan, kualitas pekerjaan yang diselesaikan kurang baik dan rendahnya disiplin karyawan, serta keinginan untuk pindah tempat kerja semakin tinggi. Kepuasan kerja tercipta, jika harapan karyawan dapat dipenuhi oleh perusahaan.

Menurut artikel Schmerhorn (2010:1), yang diperoleh dari situs: http://id.wikipedia.org.,"Faktor-faktor yang mempengaruhi kepuasan kerja adalah pekerjaan itu sendiri, penyelia, teman sekerja (rekan kerja), promosi jabatan, gaji atau upah. Aspek-aspek lain yang terdapat dalam kepuasan kerja yang dalam artikel Stephen Robins (2010:1), yang diperoleh dari situs: http://id.wikipedia.org. diketahui "faktor yang mempengaruhi kepuasan kerja adalah kerja yang secara mental menantang, ganjaran yang pantas, kondisi kerja yang mendukung, rekan kerja yang mendukung dan kesesuaian 


\section{Volume 19 Nomor 2}

kepribadian dengan pekerjaan" Apabila salah satu faktor tersebut berubah, maka kepuasan kerja karyawan akan berubah.

Berikut ini disajikan beberapa hasil penelitian tentang Faktor-Faktor yang Mempengaruhi Kepuasan Kerja Karyawan:

a. Penelitian Yulinda dan Harlyanti (2009), mengungkapkan faktor yang dominan mempengaruhi kepuasan kerja pegawai pada bagian dinas luar asuransi jiwa bersama Bumi Putera 1912 Cabang Setiabudi Medan adalah kesempatan untuk maju (promosi jabatan), upah dan gaji, hubungan dengan rekan kerja.

b. Hasil penelitian Rahayuningsih pada tahun 2006, menyimpulkan bahwa" kepuasan kerja mempengaruhi cara karyawan mengevaluasi aspek pekerjaan atau lingkungan pekerjaan seperti: kepuasan terhadap gaji, kondisi kerja dan supervisor. Kepuasan kerja yang meningkat berarti perbaikan kualitas hidup yang lebih baik, kesehatan, mental maupun physical. Kepuasan kerja berdampak pada non work seperti tingkat kehadiran, perputaran kerja, kesehatan organisasi, kualitas dan kuantitas pekerjaaan serta kesehatan mental dan fisik pekerja".

c. Hasil penelitian Kurniasih (2005), menunjukkan bahwa faktor yang dominan mempengaruhi kepuasan kerja karyawan adalah gaji, promosi jabatan, hubungan kerja, dan lingkungan kerja. Dari keempat faktor dominan tersebut, yang paling dominan adalah faktor gaji.

PT Astra Cabang Medan adalah perusahaan jasa yang bergerak dibidang penjualan mobil, service kenderaan dan suku cadang Toyota. Perusahaan ini adalah salah satu mean dealer dan bengkel resmi Toyota yang berada dibawah pengawasan PT Astra Motor Tbk, Jakarta. Produk yang dipasarkan perusahaan adalah Vios, Corolla Altis, Camry, Yarris, Avanza, Rush, Kijang Innova, Fortuner, Hilux, Previa, Alphard, Corwn Royal, Land Cruiser dan Truk Dyna. Untuk meningkatkan kepuasan kerja karyawan, perusahaan memberikan gaji pokok, insentif/bonus berdasarkan penjualan, fasilitas kendaraan dinas, pakaian seragam, kesempatan untuk dipromosikan ke jabatan yang lebih tinggi, tunjangan keluarga dan tunjangan anak serta biaya pengobatan dan perawatan karyawan yang sakit.

Berdasarkan penelitian pendahuluan diketahui. Karyawan PT Astra Cabang Medan sering mengeluh karena insentif atau bonus yang diberikan perusahaan belum sesuai yang diharapkan oleh karyawan, dan kendaraan dinas tidak diberikan kepada semua karyawan, pimpinan kadang bersikap diktator kepada bawahan tanpa memperhatikan kemampuan bawahan dalam menyelesaikan pekerjaan yang dibebankan, selain itu, juga disebabkan karena biaya pengobatan dan perawatan karyawan yang sakit tidak seluruhnya ditanggung oleh perusahaan. Dari uraian di atas, penulis tertarik melakukan penelitian dengan judul : Analisis Faktor-faktor yang Mempengaruhi Kepuasan Kerja Karyawan di PT Astra Cabang Medan.

\section{TINJAUAN PUSTAKA}

\section{A. Teori Kepuasan Kerja}

Kepuasan kerja cenderung berdampak pada kinerja karyawan, tingkat kehadiran, dan tingkat keluar masuknya karyawan (turnover). Organisasi dengan karyawan yang lebih puas cenderung memiliki kinerja dan tingkat kehadiran yang lebih tinggi serta turnover yang lebih rendah dibandingkan dengan organisasi yang memiliki karyawan yang kurang puas.

Menurut Gibson dan Donnelly (2011: 70), ada beberapa teori tentang kepuasan kerja, antara lain:

a. Teori ketidaksesuaian atau pertentangan (discrepancy theory). Kepuasan dinilai dari dua aspek yaitu adanya pertentangan yang dipersepsikan antara apa yang diinginkan dengan apa yang diterima dan pentingnya apa yang diinginkan bagi individu. Seseorang 


\section{Volume 19 Nomor 2}

terpuaskan jika tidak ada selisih antara kondisi yang diinginkan dengan yang kenyataannya.

b. Teori keadilan (equity theory). Komponen utama dari teori ini adalah input, hasil dan bahan perbandingan. Kepuasan akan diperoleh dengan membandingkan rasio input dengan hasil melalui perbandingan dengan orang lain. Jika hasil perbandingan tersebut tidak adil (sesuai), maka individu akan memperoleh ketidakpuasan.

c. Teori dua faktor (two factor theory). Toeri ini menyatakan bahwa kepuasan kerja secara kualitatif berbeda dengan ketidakpuasan kerja.

d. Teori pemenuhan kebutuhan (need fulfilment theory). Kepuasan kerja sangat tergantung pada terpenuhi atau tidaknya kebutuhan individu oleh pekerjaan atau organisasinya.

e. Teori pandangan kelompok (social reference group theory).Kepuasan kerja sangat ditentukan oleh pandangan dan pendapat kelompok yang dianggap sebagai tolok ukur untuk menilai dia dan lingkungannya.

\section{B. Faktor-faktor yang Mempengaruhi Kepuasan Kerja Karyawan.}

Menurut Sutrisno (2009: 83), faktor-faktor yang mempengaruhi kepuasan kerja karyawan adalah:

1. Kesempatan untuk maju. Dalam hal ini, ada tidaknya kesempatan untuk memperoleh pengalaman dan peningkatan kemampuan selama bekerja. Kesempatan untuk maju tersebut, dapat dilihat dari adanya peluang bagi karyawan untuk menduduki jabatan yang lebih tinggi.

2. Gaji. Gaji lebih banyak menyebabkan ketidakpuasan, dan jarang orang mengekspresikan kepuasan kerjanya dengan sejumlah uang yang diperolehannya.

3. Kondisi kerja. Kondisi kerja merupakan situasi dimana karyawan bekerja, termasuk ventilasi, penyinaran, kantin dan tempat parkir.

4. Faktor instrinsik pekerjaan. Atribut yang ada dalam pekerjaan mensyaratkan keterampilan tertentu. Sukar dan mudanya serta kebanggaan akan tugas dapat meningkatkan atau mengurangi kepuasan kerja.

5. Komunikasi. Dalam hal ini, ada kesediaan pihak atasan untuk mendengar, memahami dan mengakui pendapat ataupun prestasi bawahannya sangat berperan dalam meningkatkan kepuasan kerja.

6. Pekerjaan yang menantang. Pekerjaan yang menantang akan memotivasi mereka untuk bekerja kerja, sehingga bila pekerjaan tersebut dapat diselesaikan, maka karyawan merasa puas.

7. Penempatan yang sesuai kemampuan. Jika penempatan tenaga kerja sesuai kemampuannya, maka mereka merasa puas. Akan tetapi, jika penempatan tersebut tidak sesuai kemampuan bawahan, maka mereka menjadi stres dan frustasi, sehingga mereka merasa tidak puas.

8. Kepemimpinan. Kepemimpinan merupakan proses mengarahkan dan mempengaruhi aktivitas yang berkaitan dengan pekerjaan dari anggota kelompok. Salah satu tantangan yang dihadapi pemimpin adalah bagaimana ia menggerakkan bawahannya, agar mau dan bersedia bekerja.

9. Atasan yang memperlakukan karyawan secara adil, baik dalam hal pemberian balas maupun pembagian tugas. Jika karyawan merasa diperlakuan secara adil oleh atasan, maka mereka merasa puas.

\section{METODE PENELITIAN}

\section{A. Populasi dan Sampel}

Populasi dalam penelitian ini adalah seluruh karyawan PT Astra Cabang Medan tahun 2017 sebanyak 132 orang. Menurut Hair, dkk., (2000: 365), "jumlah sampel dalam analisis 


\section{Volume 19 Nomor 2}

faktor adalah $5 \times \mathrm{n}$ ". Penelitian ini menggunakan 21 variabel (n), maka yang menjadi sampel penelitian adalah $5 \times 21=105$ orang. Penentuan sampel dilakukan secara acak sederhana. Populasi dan sampel penelitian disajikan pada tabel berikut:

Tabel 1. Populasi dan Sampel Penelitian

\begin{tabular}{|l|l|l|}
\hline URAIAN & Populasi (orang) & Sampel (orang) \\
\hline Sales Departement & 42 & $42: 132 \times 105=33$ \\
Administration Departement & 28 & $28: 132 \times 105=22$ \\
Service Departement & 34 & $34: 132 \times 105=27$ \\
Parts Departement & 16 & $16: 132 \times 105=13$ \\
Customer Relation Officer & 12 & $12: 132 \times 105=10$ \\
\cline { 2 - 3 } Jumlah & 132 & 105 \\
\hline
\end{tabular}

Sumber: PT Astra Cabang Medan

\section{B. Variabel Penelitian dan Defenisi Operasional}

Variabel yang digunakan dalam penelitian ini yaitu:

1. Gaji pokok, yaitu balas jasa yang diberikan oleh perusahaan kepada karyawan untuk memenuhi kebutuhan pokoknya.

2. Insentif atau bonus, yaitu penghargaan yang diberikan perusahaan kepada karyawan berdasarkan hasil penjualan mobil kepada pelanggan.

3. Tunjangan keluarga, yaitu tambahan balas jasa yang diberikan kepada karyawan yang sudah berkeluarga, berupa tunjangan istri/suami dan anak.

4. Biaya pengobatan dan perawatan, yaitu bantuan biaya pengobatan dan perawatan yang diberikan perusahaan kepada karyawan yang sakit.

5. Tanda jasa, yaitu penghargaan yang diberikan kepada karyawan yang memiliki loyalitas diukur dari masa kerja karyawan.

6. Jamsostek, yaitu asuransi jaminan sosial dan kesehatan yang diberikan oleh perusahaan kepada karyawan.

7. Kendaraan dinas, yaitu fasilitas yang diberikan perusahaan kepada karyawan untuk memperlancar pelaksanaan tugas yang dibebankan oleh atasan.

8. Promosi jabatan, yaitu kesempatan yang diberikan kepada karyawan yang berprestasi terbaik untuk menduduki jabatan yang lebih tinggi.

9. Perlakuan adil, yaitu pemberian balas jasa sesuai beban tugas yang dibebankan oleh atasan kepada bawahan.

10. Kondisi kerja, yaitu situasi tempat dimana karyawan menyelesaikan tugas-tugasnya.

11. Kebijakan dan prosedur kerja, yaitu ketentuan mengenai tata cara penyelesaian tugastugas yang dibebankan oleh atasan kepada bawahan.

12. Kelompok kerja, yaitu bagian yang terdiri dari beberapa orang karyawan untuk menyelesaikan pekerjaan yang sama.

13. Pujian, yaitu penghargaan yang diberikan oleh atasan langsung kepada karyawan yang berprestasi, baik pujian lisan maupun tulisan.

14. Tanggungjawab, yaitu kepercayaan yang diberikan oleh atasan kepada bawahan untuk menyelesaikan suatu pekerjaan.

15. Faktor instrinsik dari pekerjaan adalah persyaratan keterampilan yang dibutuhkan untuk menyelesaikan suatu pekerjaan.

16. Komunikasi antar rekan kerja, yaitu hubungan yang terjalin antar sesama pekerja.

17. Komunikasi antar atasan dengan bawahan, yaitu keharmonisan hubungan yang terjalin diantara para karyawan.

18. Penempatan sesuai kemampuan, yaitu penempatan karyawan sesuai kemampuan dan keterampilan yang dimiliki. 


\section{Volume 19 Nomor 2}

19. Pekerjaan yang menantang, yaitu tugas yang dibebankan oleh atasan kepada bawahan bersifat menantang.

20. Kepemimpinan, yaitu sifat atau perilaku atasan kepada bawahan dalam mengambil berbagai kebijakan.

21. Rekan kerja, yaitu teman sekerja karyawan yang saling membantu dalam menyelesaikan tugas-tugas yang dibebankan oleh atasan.

\section{Metode Analisis}

\section{Uji Validitas dan Reliabilitas Instrumen}

Melakukan Uji validitas dengan analisis item, yaitu mengkorelasikan skor tiap butir dengan skor total, yang merupakan jumlah tiap skor butir. Dalam memberikan interprestasi terhadap koefisien korelasi, dimana item yang mempunyai korelasi positif dengan kriteria (skor total) serta korelasi yang tinggi, menunjukkan bahwa item tersebut mempunyai validitas yang tinggi pula.

Untuk menghitung koefisien korelasi dengan rumus:

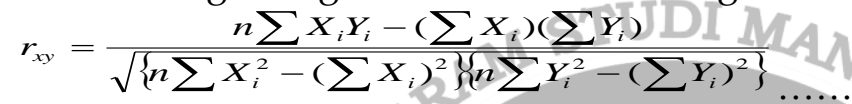

Keterangan: $X_{i}=$ Skor tiap butir, $Y=$ Skor total butir $n=$ Jumlah responden rumus:

Uji reliabilitas dilakukan dengan teknik belah dua dari Spearmen Brown dengan

Keterangan $: r_{i}=$ reliabilitas internal seluruh instrumen

$\mathrm{rb}=$ korelasi product moment antara belahan pertama dan kedua

Perhitungan reliabilitas pada penelitian ini menggunakan analisis yang dikembangkan oleh Alpha Cronbach. Kriteria pengujian sebagai berikut:

$\alpha \geq 0,5$ artinya instrumen reliabel.

$a<0,5$ artinya instrumen tidak reliabel.

\section{Analisis Faktor}

Teknik analisis data yang digunakan adalah analisis faktor untuk mereduksi data, yaitu proses untuk meringkas sejumlah variabel menjadi lebih sedikit untuk mengetahui faktor yang dominan mempengaruhi kepuasan kerja karyawan. Menurut Santoso dan Tjiptono (2001: 250), tahap-tahap analisis faktor adalah:

1. Memilih variabel yang layak dalam analisis faktor. Oleh karena analisis faktor berupaya mengelompokkan sejumlah variabel maka seharusnya ada korelasi yang cukup kuat di antara variabel sehingga akan terjadi pengelompokkan. Alat seperti MSA atau Barlett's Test dapat digunakan untuk keperluan ini.

2. Setelah sejumlah variabel terpilih, maka dilakukan ekstraksi variabel tersebut sampai menjadi satu atau beberapa faktor. Beberapa metode pencarian faktor yang populer adalah Principal Component dan Maximum Likehood.

3. Faktor yang terbentuk, pada banyak kasus, kurang menggambarkan perbedaan di antara faktor-faktor yang ada.

4. Setelah faktor benar-benar sudah terbentuk, maka proses dilanjutkan dengan menamakan faktor yang ada.

Model dasar analisis faktor adalah data hasil observasi dari beberapa faktor $\left(f_{n}\right)$. Secara matematis persamaan ini menjadi (Arikunto, 2002: 165):

$$
X_{\text {in }}=\lambda_{1} f_{1}+\lambda_{2} f_{2}+\ldots . .+\lambda_{n} f_{n}+e_{i n}
$$

2

Keterangan: $X_{\text {in }}=$ Nilai dari variabel ke-i untuk observasi ke-n

$\mathrm{f}_{1}=$ Faktor-faktor yang mempengaruhi kepuasan kerja karyawan

$\lambda_{\mathrm{i}}=$ Hubungan antar variabel 


\section{Volume 19 Nomor 2}

$\lambda_{\mathrm{ij}}$ yang biasa disebut factor loading, menunjukkan keterkaitan faktor dengan variabel yang diukur. Secara spesifik dapat dikatakan bahwa factor loading adalah korelasi antara faktor dengan variabel. Jika nilai KMO (Kaiser Meyer Olkin) Measure of Sampling Adeguarcy (MSA) lebih besar 0,50, maka kumpulan variabel tersebut dapat diproses lebih lanjut.

Angka pembatas (cut off point), agar sebuah variabel dapat secara nyata termasuk sebuah faktor adalah 0,50 . Jika sebuah faktor loadingnya $\geq 0,50$, variabel dapat dimasukkan sebagai suatu faktor. Jika hasil perhitungan faktor loadingnya $<0,50$, maka variabel tidak dapat dimasukkan dalam salah satu faktor manapun. Selanjutnya dilakukan analisis:

a. KMO (Kaiser Meyer Olkin) menunjukkan apakah sampel penelitian dapat diproses lebih lanjut.

b. Communalities menunjukkan nilai faktor yang menjelaskan varian masing-masing faktor.

c. Total variance expained menunjukkan nilai tiap variabel yang dianalisis. Penentuan jumlah faktor yang terbentuk didasarkan atas nilai eigenvalues lebih besar atau sama dengan satu.

d. Component matrix menunjukkan nilai korelasi antara suatu variabel dengan faktor yang terbentuk.

e. Rotated component matrix adalah memperjelas dan menegaskan variabel-variabel mana yang masuk ke dalam tiap-tiap faktor.

f. Component transformation matrix menunjukkan adanya interkorelasi antara faktor yang terbentuk.

Pengujian dilakukan dengan bantuan program SPSS versi 20,0.

\section{HASIL PENELITIAN DAN PEMBAHASAN}

\section{A. Hasil Uji Validitas dan Reliabilitas}

Hasil uji secara simultan adalah:

Tabel 2. Case Processing Summary Mengenai Kepercayaan Pelanggan

\begin{tabular}{|ll|l|l|}
\hline & & $\mathrm{N}$ & $\%$ \\
\hline Cases & Valid & 30 & 100.0 \\
& Excluded(a) & 0 & .0 \\
& Total & 30 & 100.0 \\
\hline
\end{tabular}

a Listwise deletion based on all variables in the procedure.

Dari tabel di atas, terlihat bahwa jawaban 30 responden $100 \%$ sudah valid. Hasil uji reliabilitas secara simultan disajikan pada tabel berikut:

Tabel 3. Reliability Statistics

\begin{tabular}{|l|l|}
\hline Cronbach's Alpha & Nof Items \\
\hline 0,942 & 21 \\
\hline
\end{tabular}

Sumber: Hasil Pengolahan data SPSS Versi 20,0

Dari tabel diatas, terlihat bahwa kedua puluh satu indikator pengukuran variabel penelitian sudah reliabel, karena nilai cronbach's alpha sebesar 0,942 >0,50.

Tabel 4. Item-Total Statistics

\begin{tabular}{|l|l|l|l|l|}
\hline \multicolumn{1}{|c|}{ Variabel penelitian } & Correlation & \multicolumn{1}{c|}{ Ket. } & \multicolumn{1}{c|}{$\begin{array}{c}\text { Cronbach's Alpha if } \\
\text { Item }\end{array}$} & \multicolumn{1}{|c|}{ Ket. } \\
\hline Gaji pokok (V1) & 0,802 & Valid & 0,936 & Reliabel \\
\hline Insentif atau bonus (V2) & 0,489 & Valid & 0,942 & Reliabel \\
\hline Tunjangan keluarga (V3) & 0,832 & Valid & 0,936 & Reliabel \\
\hline Biaya pengobatan dan perawatan (V4) & 0,580 & Valid & 0,940 & Reliabel \\
\hline Tanda jasa (V5) & 0,784 & Valid & 0,936 & Reliabel \\
\hline Jamsostek (V6) & 0,681 & Valid & 0,938 & Reliabel \\
\hline Kendaraan dinas (V7) & 0,717 & Valid & 0,937 & Reliabel \\
\hline Promosi jabatan (V8) & 0,568 & Valid & 0,940 & Reliabel \\
\hline Perlakuan yang adil (V9) & 0,780 & Valid & 0,936 & Reliabel \\
\hline
\end{tabular}


Volume 19 Nomor 2

\begin{tabular}{|l|l|l|l|l|}
\hline \hline Kondisi kerja (V10) & 0,736 & Valid & 0,937 & Reliabel \\
\hline Kebijakan dan prosedur kerja (V11) & 0,627 & Valid & 0,939 & Reliabel \\
\hline Kelompok kerja (V12) & 0,665 & Valid & 0,938 & Reliabel \\
\hline Pujian (V13) & 0,558 & Valid & 0,940 & Reliabel \\
\hline Tanggungjawab (V14) & 0,582 & Valid & 0,940 & Reliabel \\
\hline Faktor instrinsik dari pekerjaan (V15) & 0,546 & Valid & 0,940 & Reliabel \\
\hline Komunikasi antar rekan kerja (V16) & 0,549 & Valid & 0,940 & Reliabel \\
\hline Komunikasi antar atasan dengan bawahan (V17) & 0,588 & Valid & 0,940 & Reliabel \\
\hline Penempatan sesuai kemampuan (V18) & 0,512 & Valid & 0,941 & Reliabel \\
\hline Pekerjaan yang menantang (V19) & 0,613 & Valid & 0,939 & Reliabel \\
\hline Kepemimpinan (V20) & 0,691 & Valid & 0,939 & Reliabel \\
\hline Rekan kerja (V21) & 0,588 & Valid & 0,940 & Reliabel \\
\hline
\end{tabular}

Sumber: Hasil Pengolahan data SPSS Versi 20,0

Dari tabel di atas, diketahui bahwa kedua puluh satu indikator pengukuran variabel kepuasan kerja karyawan pada PT Astra Cabang Medan, secara rata-rata valid, karena nilai $\mathrm{r}_{\text {hitung }}>0,30$.

\section{B. Hasil Penelitian}

\section{KMO and Bartlett's Test}

KMO and Bartlett's Test berguna untuk mengetahui apakah variabel dan data penelitian dapat dianalisis lebih lanjut atau tidak, ternyata didapat hasil sebagai berikut:

Tabel 5. KMO and Bartlett's Test

Kaiser-Meyer-Olkin Measure of Sampling Adequacy.

Bartlett's Test of Sphericity

Approx. Chi-Square
Df
Sig.

0,825

725,519

210

0,000

Sumber: Hasil Pengolahan data Versi SPSS 20

Dari tabel di atas, terlihat angka KMO (Kaiser-Meyer-Olkin) Measure of Sampling Adeguacy (MSA) adalah 0,825 dengan tingkat signifikansi 0,000, maka data cukup layak dianalisis lebih lanjut dengan menggunakan analisis faktor.

\section{Anti Image Correlation}

Anti image correlation menunjukkan variabel mana yang dapat diproses lebih lanjut dan mana yang harus dikeluarkan sebagai variabel penelitian. Pada tabel Anti Image Matrices, di bagian Anti Image Correlation terlihat sejumlah angka yang membentuk diagonal yang menandakan besaran Measure of Sampling Adeguacy (MSA) masing-masing variabel, seperti yang disajikan pada lampiran 4 . Berdasarkan lampiran 4, terlihat nilai MSA yang dilihat dari diagonalnya (bertanda a) adalah 0,$855 ; 0,722 ; 0,850 ; 0,618 ; 0,882 ; 0,843 ; 0,703 ; 0,766 ; 0,881$; 0,$806 ; 0,836 ; 0,885 ; 0,838 ; 0 ; 840 ; 0,815 ; 0,859 ; 0,802 ; 0,856 ; 0,815 ; 0,709$ dan 0,833 . Dari angka tersebut terlihat bahwa seluruh nilai MSA berada di atas 0,50, artinya variabel penelitian masih bisa diprediksi dan dianalisis lebih lanjut dengan mengikutkan 21 faktor yang mempengaruhi kepuasan kerja karyawan PT Astra Cabang Medan.

Anti image covariance, menunjukkan nilai korelasi antara suatu variabel dengan variabel lainnya. Berdasarkan lampiran 4, diketahui nilai covariance untuk variabel gaji pokok $\left(\mathrm{V}_{1}\right)$ dengan insentif atau bonus $\left(\mathrm{V}_{2}\right)$ sebesar 0,003 , artinya jika gaji tinggi dan insentif atau bonus tinggi, maka karyawan merasa puas. Nilai covariance variabel gaji pokok $\left(\mathrm{V}_{1}\right)$ dengan biaya pengobatan dan perawatan $\left(\mathrm{V}_{4}\right)$ sebesar negatif 0,052 , artinya jika gaji pokok rendah, maka biaya pengobatan dan perawatan yang ditanggung perusahaan rendah. Demikian, penjelasan seterusnya.

\section{Pembahasan}




\section{Volume 19 Nomor 2}

\section{Communalities}

Communalities memberikan gambaran tentang persentase keragaman dari suatu variabel asal yang dapat dijelaskan oleh faktor yang ada.

Tabel 6 Communalities

\begin{tabular}{|l|l|l|}
\hline Variabel & Initial & Extraction \\
\hline Gaji pokok (V1) & 1,000 & 0,557 \\
\hline Insentif atau bonus (V2) & 1,000 & 0,803 \\
\hline Tunjangan keluarga (V3) & 1,000 & 0,620 \\
\hline Biaya pengobatan dan perawatan (V4) & 1,000 & 0,655 \\
\hline Tanda jasa (V5) & 1,000 & 0,492 \\
\hline Jamsostek (V6) & 1,000 & 0,695 \\
\hline Kendaraan dinas (V7) & 1,000 & 0,626 \\
\hline Promosi jabatan (V8) & 1,000 & 0,646 \\
\hline Perlakuan adil (V9) & 1,000 & 0,639 \\
\hline Kondisi kerja (V10) & 1,000 & 0,682 \\
\hline Kebijakan dan prosedur kerja (V11) & 1,000 & 0,698 \\
\hline Kelompok kerja (V12) & 1,000 & 0,507 \\
\hline Pujian (V13) & 1,000 & 0,535 \\
\hline Tanggungjawab (V14) & 1,000 & 0,687 \\
\hline Faktor instrinsik dari pekerjaan (V15) & 1,000 & 0,628 \\
\hline Komunikasi antar rekan kerja (V16) & 1,000 & 0,638 \\
\hline Komunikasi antar atasan dengan bawahan (V17) & 1,000 & 0,638 \\
\hline Penempatan sesuai kemampuan (V18) & 1,000 & 0,678 \\
\hline Pekerjaan yang menantang (V19) & 1,000 & 0,548 \\
\hline Kepemimpinan (V20) & 1,000 & 0,600 \\
\hline Rekan kerja (V21) & 1,000 & 0,575 \\
\hline
\end{tabular}

Extraction Method: Principal Component Analysis

1. Variabel tanda jasa, angka 0,492 artinya tanda jasa dapat menjelaskan 49,2 persen varians yang terbentuk.

2. Variabel jamsostek, angka 0,695 artinya jamsostek dapat menjelaskan 69,5 persen varians yang terbentuk.

3. Variabel kendaraan dinas, angka 0,626 artinya kendaraan dinas dapat menjelaskan 62,6 persen varians yang terbentuk.

4. Variabel promosi jabatan, angka 0,646 artinya promosi jabatan dapat menjelaskan 64,6 persen varians yang terbentuk.

5. Variabel perlakuan adil, angka 0,639 artinya perlakuan adil dapat menjelaskan 63,9 persen varians yang terbentuk.

6. Variabel kondisi kerja, angka 0,682 artinya kondisi kerja dapat menjelaskan 68,2 persen varians yang terbentuk.

7. Variabel kebijakan dan prosedur kerja, angka 0,698 artinya kebijakan dan prosedur kerja dapat menjelaskan 69,8 persen varians yang terbentuk.

8. Variabel kelompok kerja, angka 0,507 artinya kelompok kerja dapat menjelaskan 50,7 persen varians yang terbentuk.

9. Variabel pujian, angka 0,535 artinya pujian dapat menjelaskan 53,5 persen varians yang terbentuk.

10. Variabel tanggung jawab, angka 0,687 artinya tanggung jawab dapat menjelaskan 68,7 persen varians yang terbentuk.

11. Variabel faktor instrinsik dari pekerjaan, angka 0,628 artinya faktor instrinsik dari pekerjaan dapat menjelaskan 62,8 persen varians yang terbentuk. 


\section{Volume 19 Nomor 2}

12. Variabel komunikasi antar rekan kerja, angka 0,638 artinya komunikasi antar rekan kerja dapat menjelaskan 63,8 persen varians yang terbentuk.

13. Variabel komunikasi antar atasan dengan bawahan, angka 0,638 artinya komunikasi antar atasan dengan bawahan dapat menjelaskan 63,8 persen varians yang terbentuk.

14. Variabel penempatan sesuai kemampuan, angka 0,678 artinya penempatan sesuai kemampuan dapat menjelaskan 67,8 persen varians yang terbentuk.

15. Variabel pekerjaan yang menantang, angka 0,548 artinya pekerjaan yang menantang dapat menjelaskan 54,8 persen varians yang terbentuk.

16. Variabel kepemimpinan, angka 0,600 artinya kepemimpinan dapat menjelaskan 60 persen varians yang terbentuk.

17. Variabel rekan kerja, angka 0,575 artinya rekan kerja menjelaskan 60 persen varians yang terbentuk.

\section{Total Variance Explained}

Ttotal variance explained dan initial eigen value menunjukkan nilai eigenvalue untuk masing-masing faktor sebanyak variabel aslinya.

Tabel 7. Total Variance Explained

\begin{tabular}{|c|c|c|c|c|c|c|}
\hline \multirow{2}{*}{$\begin{array}{l}\text { Compone } \\
n t\end{array}$} & \multicolumn{3}{|c|}{ Initial Eigenvalues } & \multicolumn{3}{|c|}{ Extraction Sums of Squared Loadings } \\
\hline & Total & $\%$ of Variance & Cumulative \% & Total & $\%$ of Variance & Cumulative \% \\
\hline 1 & 6,082 & 28,961 & 28,961 & 6,082 & 28,961 & 28,961 \\
\hline 2 & 2,035 & 9,690 & 38,651 & 2,035 & 9,690 & 38,651 \\
\hline 3 & 1,495 & 7,118 & 45,769 & 1,495 & 7,118 & 45,769 \\
\hline 4 & 1,338 & 6,373 & 52,142 & 1,338 & 6,373 & 52,142 \\
\hline 5 & 1,156 & 5,504 & 57,646 & 1,156 & 5,504 & 57,646 \\
\hline 6 & 1,040 & 4,953 & 62,599 & 1,040 & 4,953 & 62,599 \\
\hline 7 & 0,916 & 4,364 & 66,963 & & & \\
\hline 8 & 0,836 & 3,983 & 70,946 & & & \\
\hline 9 & 0,779 & 3,709 & 74,655 & & & \\
\hline 10 & 0,724 & 3,448 & 78,104 & & & \\
\hline 11 & 0,638 & 3,040 & 81,144 & & & \\
\hline 12 & 0,545 & 2,593 & 83,737 & & & \\
\hline 13 & 0,530 & 2,524 & 86,261 & & & \\
\hline 14 & 0,519 & 2,469 & 88,731 & & & \\
\hline 15 & 0,451 & 2,150 & 90,881 & & & \\
\hline 16 & 0,413 & 1,966 & 92,847 & & & \\
\hline 17 & 0,377 & 1,793 & 94,640 & & & \\
\hline 18 & 0,331 & 1,576 & 96,216 & & & \\
\hline 19 & 0,283 & 1,350 & 97,566 & & & \\
\hline 20 & 0,260 & 1,237 & 98,802 & & & \\
\hline 21 & 0,251 & 1,198 & 100,000 & & & \\
\hline
\end{tabular}

Extraction Method: Principal Component Analysis

Susunan eigenvalues selalu diurutkan dari yang terbesar sampai terkecil, dengan kriteria bahwa angka eigenvalues di bawah 1 tidak digunakan dalam menghitung jumlah faktor yang terbentuk. Jika 21 faktor tersebut diringkas menjadi satu faktor, maka varians yang dapat dijelaskan oleh satu faktor tersebut, sebagai berikut:
a. Varians faktor pertama adalah
$6,082: 21 \times 100 \%=28,961$ persen
b. Varians faktor kedua adalah
$2,035: 21 \times 100 \%=9,690$ persen
c. Varians faktor ketiga adalah
$1,495: 21 \times 100 \%=7,118$ persen
d. Varians faktor keempat adalah
$1,338: 21 \times 100 \%=6,373$ persen 


\section{Volume 19 Nomor 2}

e. Varians faktor kelima adalah

f. Varians faktor keenam adalah Total varians

$$
\begin{aligned}
& 1,156: 21 \times 100 \%=5,504 \text { persen } \\
& 1,040: 21 \times 100 \%=\frac{4,953 \text { persen }+}{62,599 \text { persen }}
\end{aligned}
$$

Eigenvalues menunjukkan kepentingan relatif masing-masing faktor dalam menghitung varians 21 faktor yang dianalisis. Jumlah angka eigenvalues untuk 21 faktor variabel adalah $\{(6,082+2,035+1,495+1,338+1,156+1,040+0,916+0,836+0,779+0,724+$ $0,638+0,545+0,530+0,519+0,451+0,413+0,377+0,331+0,283+0,260+0,251)\}=21$. Nilai eigen value yang lebih besar dari satu terdiri dari 6 faktor, sehingga 21 faktor dapat dijadikan menjadi 6 faktor yang secara bersama dapat menjelaskan varians total sebesar 62,599 persen.

Dari data diatas, diperoleh scree plot yang menampakkan grafik, di mana dari faktor pertama ke faktor kedua (garis sumber component number $=1$ ke 2), arah garis menurun tajam, dari faktor kedua ke faktor keenam, arah garis menurun cukup tajam. Kemudian dari faktor ketujuh sampai faktor kedua puluh satu sudah berada di bawah angka dari sumbu $Y$ (eigenvalues), arah garis menurun dengan slope yang semakin kecil. Hal ini menunjukkan bahwa 6 faktor paling bagus untuk meringkas 21 faktor yang mempengaruhi kepuasan kerja karyawan.

\section{Component Matrix}

Component matrix yaitu besar korelasi antara tiap variabel dengan faktor 1, faktor 2, faktor 3, faktor 4, faktor 5 dan faktor 6. Penentuan variabel dari masing-masing faktor dilakukan dengan membandingkan besaran korelasi pada setiap baris. Angka korelasi di bawah 0,50 mengindikasikan korelasi yang lemah, dan jika korelasinya di atas 0,50 berindikasi kuat korelasinya.

Tabel 8. Component Matrix(a)

\begin{tabular}{|l|l|l|l|l|l|l|}
\hline \multirow{2}{*}{ Indikator penelitian } & \multicolumn{4}{l}{ Component } \\
\cline { 2 - 7 } & 1 & 2 & 3 & 4 & 5 & 6 \\
\hline Gaji pokok (V1) & 0,660 & $-0,178$ & $-0,248$ & $-0,097$ & $-0,124$ & $-0,061$ \\
\hline Insentif atau bonus (V2) & 0,301 & 0,179 & 0,037 & $-0,220$ & 0,560 & 0,563 \\
\hline Tunjangan keluarga (V3) & 0,522 & 0,190 & 0,498 & $-0,156$ & 0,136 & $-0,141$ \\
\hline Biaya pengobatan dan perawatan (V4) & 0,315 & 0,062 & 0,271 & $-0,685$ & $-0,046$ & 0,083 \\
\hline Tanda jasa (V5) & 0,577 & $-0,198$ & 0,343 & 0,024 & $-0,008$ & 0,041 \\
\hline Jamsostek (V6) & 0,650 & 0,138 & 0,157 & $-0,172$ & 0,067 & $-0,441$ \\
\hline Kendaraan dinas (V7) & 0,360 & $-0,104$ & 0,276 & 0,517 & 0,366 & $-0,088$ \\
\hline Promosi jabatan (V8) & 0,528 & 0,423 & $-0,390$ & 0,128 & $-0,135$ & 0,036 \\
\hline Perlakuan adil (V9) & 0,665 & $-0,314$ & $-0,253$ & $-0,070$ & $-0,087$ & $-0,147$ \\
\hline Kondisi kerja (V10) & 0,601 & $-0,271$ & $-0,260$ & 0,032 & 0,422 & $-0,016$ \\
\hline Kebijakan dan prosedur kerja (V11) & 0,624 & $-0,404$ & $-0,265$ & $-0,173$ & 0,142 & 0,159 \\
\hline Kelompok kerja (V12) & 0,616 & $-0,116$ & 0,125 & $-0,053$ & 0,030 & $-0,309$ \\
\hline Pujian (V13) & 0,608 & $-0,264$ & 0,112 & $-0,153$ & $-0,235$ & $-0,067$ \\
\hline Tanggungjawab (V14) & 0,510 & $-0,419$ & 0,027 & 0,106 & $-0,389$ & 0,297 \\
\hline Faktor instrinsik dari pekerjaan (V15) & 0,381 & $-0,056$ & 0,603 & 0,172 & $-0,183$ & 0,230 \\
\hline Komunikasi antar rekan kerja (V16) & 0,657 & 0,417 & $-0,138$ & 0,096 & $-0,018$ & $-0,055$ \\
\hline Komunikasi antar atasan (V17) & 0,415 & 0,465 & 0,154 & 0,410 & $-0,233$ & 0,054 \\
\hline Penempatan sesuai kemampuan (V18) & 0,591 & 0,264 & $-0,097$ & $-0,013$ & $-0,267$ & 0,423 \\
\hline Pekerjaan yang menantang (V19) & 0,522 & 0,435 & $-0,014$ & 0,143 & 0,257 & 0,012 \\
\hline Kepemimpinan (V20) & 0,377 & $-0,525$ & $-0,085$ & 0,407 & 0,089 & 0,038 \\
\hline Rekan kerja (V21) & 0,553 & 0,402 & $-0,292$ & $-0,074$ & $-0,065$ & $-0,115$ \\
\hline
\end{tabular}

Extraction Method: Principal Component Analysis. a 3 components extracted.

Berdasarkan tabel 7, dapat dijelaskan arti component matrix sebagai berikut: 


\section{Volume 19 Nomor 2}

1. Variabel gaji pokok (V1), korelasi antara variabel ini dengan faktor 1 sebesar 0,660 (cukup kuat). Dengan demikian, variabel ini dapat dimasukkan sebagai komponen faktor 1.

2. Variabel insentif atau bonus (V2), korelasi antara variabel ini dengan faktor 6 sebesar 0,563 (cukup kuat). Dengan demikian, variabel ini dapat dimasukkan sebagai komponen faktor 6.

3. Variabel tunjangan keluarga (V3), korelasi antara variabel ini dengan faktor 1 sebesar 0,522 (cukup kuat). Dengan demikian, variabel ini dapat dimasukkan sebagai komponen faktor 1 .

4. Variabel biaya pengobatan dan perawatan (V4), korelasi antara variabel ini dengan faktor 4 sebesar -0,685 (cukup kuat). Dengan demikian, variabel ini dapat dimasukkan sebagai komponen faktor 4.

5. Variabel tanda jasa (V5), korelasi antara variabel ini dengan faktor 1 sebesar 0,577 (cukup kuat). Dengan demikian, variabel ini dapat dimasukkan sebagai komponen faktor 1.

6. Variabel jamsostek (V6), korelasi antara variabel ini dengan faktor 1 sebesar 0,650 (cukup kuat). Dengan demikian, variabel ini dapat dimasukkan sebagai komponen faktor 1.

7. Variabel kendaraan dinas (V7), korelasi antara variabel ini dengan faktor 4 sebesar 0,517 (cukup kuat). Dengan demikian, variabel ini dapat dimasukkan sebagai komponen faktor 4 .

8. Variabel promosi jabatan (V8), korelasi antara variabel ini dengan faktor 1 sebesar 0,528 (cukup kuat). Dengan demikian, variabel ini dapat dimasukkan sebagai komponen faktor 1.

9. Variabel perlakuan adil (V9), korelasi antara variabel ini dengan faktor 1 sebesar 0,665 (kuat). Dengan demikian, variabel ini dapat dimasukkan sebagai komponen faktor 1.

10. Variabel kondisi kerja (V10), korelasi antara variabel ini dengan faktor 1 sebesar 0,601 (cukup kuat). Dengan demikian, variabel ini dapat dimasukkan sebagai komponen faktor 1 .

11. Variabel kebijakan dan prosedur kerja (V11), korelasi antara variabel ini dengan faktor 1 sebesar 0,624 (cukup kuat). Dengan demikian, variabel ini dapat dimasukkan sebagai komponen faktor 1.

12. Variabel kelompok kerja (V12), korelasi antara variabel ini dengan faktor 1 sebesar 0,616 (cukup kuat). Dengan demikian, variabel ini dápat dimasukkan sebagai komponen faktor 1.

13. Variabel pujian (V13), korelasi antara variabel ini dengan faktor 1 sebesar 0,608 (cukup kuat). Dengan demikian, variabel ini dapat dimasukkan sebagai komponen faktor 1.

14. Variabel tanggung jawab (V14), korelasi antara variabel ini dengan faktor 1 sebesar 0,510 (cukup kuat). Dengan demikian, variabel ini dapat dimasukkan sebagai komponen faktor 1.

15. Variabel faktor instrinsik dari pekerjaan (V15), korelasi antara variabel ini dengan faktor 3 sebesar 0,603 (cukup kuat). Dengan demikian, variabel ini dapat dimasukkan sebagai komponen faktor 3.

16. Variabel komunikasi antar rekan kerja (V16), korelasi antara variabel ini dengan faktor 1 sebesar 0,657 (cukup kuat). Dengan demikian, variabel ini dapat dimasukkan sebagai komponen faktor 1.

17. Variabel komunikasi antar atasan dengan bawahan (V17), korelasi antara variabel ini dengan faktor manapun lemah Dengan demikian, variabel ini tidak dapat dimasukkan sebagai komponen faktor manapun.

18. Variabel penempatan sesuai kemampuan (V18), korelasi antara variabel ini dengan faktor 1 sebesar 0,591 (cukup kuat). Dengan demikian, variabel ini dapat dimasukkan sebagai komponen faktor 1 . 


\section{Volume 19 Nomor 2}

19. Variabel pekerjaan yang menantang (V19), korelasi antara variabel ini dengan faktor 1 sebesar 0,522 (cukup kuat). Dengan demikian, variabel ini dapat dimasukkan sebagai komponen faktor1.

20. Variabel kepemimpinan (V20), korelasi antara variabel ini dengan faktor manapun masih lemah. Dengan demikian, variabel ini tidak dapat dimasukkan sebagai komponen faktor manapun.

21. Variabel rekan kerja (V21), korelasi antara variabel ini dengan faktor 1 sebesar 0,553 (cukup kuat). Dengan demikian, variabel ini dapat dimasukkan sebagai komponen faktor 1.

\section{Rotated Component Matrix}

Rotated component matrix berguna untuk memperjelas variabel-variabel mana yang masuk ke dalam tiap-tiap faktor. Suatu variabel dapat dimasukkan ke dalam suatu faktor jika nilai korelasinya di atas 0,50 .. Hasil analisis rotated component matrix disajikan pada Tabel 9 berikut ini:.

Tabel 9 : Hasil analisis rotated component matrix

\begin{tabular}{|l|l|l|l|l|l|l|}
\hline \multirow{2}{*}{ Indikator penelitian } & \multicolumn{7}{l}{ Component } \\
\cline { 2 - 8 } & 1 & 2 & 3 & 4 & 5 & 6 \\
\hline Gaji pokok (V1) & 0,648 & 0,312 & 0,180 & 0,067 & $-0,053$ & $-0,024$ \\
\hline Insentif atau bonus (V2) & 0,057 & 0,146 & 0,055 & 0,057 & 0,002 & 0,879 \\
\hline Tunjangan keluarga (V3) & 0,006 & 0,174 & 0,693 & 0,271 & 0,048 & 0,184 \\
\hline Biaya pengobatan dan perawatan (V4) & 0,130 & $-0,026$ & 0,482 & 0,164 & 0,545 & 0,284 \\
\hline Tanda jasa (V5) & 0,142 & 0,053 & 0,388 & 0,533 & 0,149 & 0,103 \\
\hline Jamsostek (V6) & 0,265 & 0,326 & 0,717 & $-0,017$ & 0,036 & $-0,054$ \\
\hline Kendaraan dinas (V7) & 0,093 & 0,069 & 0,244 & 0,187 & 0,711 & 0,115 \\
\hline Promosi jabatan (V8) & 0,208 & 0,775 & $-0,018$ & $-0,027$ & $-0,019$ & 0,016 \\
\hline Perlakuan adil (V9) & 0,735 & 0,216 & 0,209 & 0,027 & 0,024 & $-0,077$ \\
\hline Kondisi kerja (V10) & 0,632 & 0,153 & 0,179 & $-0,154$ & 0,315 & 0,322 \\
\hline Kebijakan dan prosedur kerja (V11) & 0,776 & 0,081 & 0,085 & 0,038 & 0,006 & 0,285 \\
\hline Kelompok kerja (V12) & 0,410 & 0,175 & 0,529 & 0,092 & 0,128 & $-0,068$ \\
\hline Pujian (V13) & 0,534 & 0,102 & 0,343 & 0,322 & $-0,101$ & $-0,088$ \\
\hline Tanggungjawab (V14) & 0,587 & 0,065 & $-0,095$ & 0,569 & $-0,018$ & $-0,073$ \\
\hline Faktor instrinsik dari pekerjaan (V15) & 0,012 & 0,027 & 0,266 & 0,730 & 0,141 & 0,063 \\
\hline Komunikasi antar rekan kerja (V16) & 0,184 & 0,720 & 0,264 & 0,060 & 0,073 & 0,081 \\
\hline Komunikasi antar atasan (V17) & $-0,146$ & 0,632 & 0,104 & 0,390 & 0,210 & $-0,101$ \\
\hline Penempatan sesuai kemampuan (V18) & 0,255 & 0,595 & $-0,044$ & 0,415 & $-0,195$ & 0,217 \\
\hline Pekerjaan yang menantang (V19) & 0,017 & 0,581 & 0,276 & 0,009 & 0,229 & 0,286 \\
\hline Kepemimpinan (V20) & 0,555 & $-0,066$ & $-0,089$ & 0,186 & 0,493 & $-0,034$ \\
\hline Rekan kerja (V21) & 0,217 & 0,677 & 0,214 & $-0,109$ & $-0,108$ & 0,029 \\
\hline
\end{tabular}

Extraction Method: Principal Component Analysis. Rotation Method: Varimax with Kaiser Normalization. a Rotation converged in 10 iterations.

Sumber: Hasil Pengolahan SPSS versi 20,0

Dari tabel tersebut, dapat dijelaskan arti rotated component matrix sebagai berikut:

1. Variabel gaji pokok adalah nilai korelasi variabel gaji pokok dengan faktor 1 sebelum rotasi adalah 0,660 (cukup kuat), setelah rotasi perkecil menjadi 0,648 (cukup kuat), sehingga variabel ini dimasukkan sebagai faktor 1 .

2. Variabel insentif atau bonus adalah nilai korelasi variabel insentif atau bonus dengan faktor 6 sebelum rotasi adalah 0,563 (cukup kuat), setelah rotasi diperbesar menjadi 0,879 (sangat kuat), sehingga variabel ini dimasukkan sebagai faktor 6. 


\section{Volume 19 Nomor 2}

3. Variabel tunjangan keluarga adalah nilai korelasi variabel tunjangan keluarga dengan faktor 3 sebelum rotasi adalah 0,498 (lemah), setelah rotasi diperbesar menjadi 0,693 (cukup kuat), sehingga variabel ini dimasukkan sebagai faktor 3.

4. Variabel biaya pengobatan dan perawatan adalah nilai korelasi variabel biaya pengobatan dan perawatan dengan faktor 5 sebelum rotasi adalah -0,046 (lemah), setelah rotasi diperbesar menjadi 0,545 (cukup kuat), sehingga variabel ini dimasukkan sebagai faktor 5 .

5. Variabel tanda jasa adalah nilai korelasi variabel tanda jasa dengan faktor 4 sebelum rotasi adalah 0,024 (lemah), setelah rotasi diperbesar menjadi 0,533 (cukup kuat), sehingga variabel ini dimasukkan sebagai faktor 4 .

6. Variabel jamsostek adalah nilai korelasi variabel jamsostek dengan faktor 3 sebelum rotasi adalah 0,276 (lemah), setelah rotasi diperbesar menjadi 0,717 (kuat), sehingga variabel ini dimasukkan sebagai faktor 3 .

7. Variabel kendaraan dinas adalah nilai korelasi variabel kendaraan dinas dengan faktor 5 sebelum rotasi adalah 0,366 (lemah), setelah rotasi diperbesar menjadi 0,711 (kuat), sehingga variabel ini dapat dimasukkan sebagai faktor 5 .

8. Variabel promosi jabatan adalah nilai korelasi variabel promosi jabatan dengan faktor 2 sebelum rotasi adalah 0,423 (lemah), setelah rotasi diperbesar menjadi 0,775 (kuat), sehingga variabel ini dapat dimasukkan sebagai faktor 2.

9. Variabel perlakuan adil adalah nilai korelasi variabel perlakuan adil dengan faktor 1 sebelum rotasi adalah 0,665 (cukup kuat), setelah rotasi diperbesar menjadi 0,735 (kuat), sehingga variabel ini dapat dimasukkan sebagai faktor 1

10. Variabel kondisi kerja adalah nilai korelasi variabel kondisi kerja dengan faktor 1 sebelum rotasi adalah 0,601 (cukup kuat), setelah rotasi diperbesar menjadi 0,632 (cukup kuat), sehingga variabel ini dapat dimasukkan sebagai faktor 1 .

11. Variabel kebijakan dan prosedur kerja adalah nilai korelasi variabel kebijakan dan prosedur kerja dengan faktor 1 sebelum rotasi adalah 0,716 (kuat), setelah rotasi diperbesar menjadi 0,776 (kuat), sehingga variabel ini dapat dimasukkan sebagai faktor 1 .

12. Variabel kelompok kerja adalah nilai korelasi variabel kelompok kerja dengan faktor 3 sebelum rotasi adalah 0,125 (lemah), setelah rotasi diperbesar menjadi 0,529 (cukup kuat), sehingga variabel ini dapat dimasukkan sebagai faktor 3.

13. Variabel pujian adalah nilai korelasi variabel pujian dengan faktor 1 sebelum rotasi adalah 0,608 (cukup kuat), setelah rotasi diperkecil menjadi 0,534 (cukup kuat), sehingga variabel ini dapat dimasukkan sebagai faktor 1 .

14. Variabel tanggung jawab adalah nilai korelasi variabel tanggung jawab dengan faktor 1 sebelum rotasi adalah 0,510 (cukup kuat), setelah rotasi diperbesar menjadi 0,587 (cukup kuat), sehingga variabel ini dapat dimasukkan sebagai faktor 1.

15. Variabel faktor instrinsik dari pekerjaan adalah nilai korelasi variabel faktor instrinsik dari pekerjaan dengan faktor 4 sebelum rotasi adalah 0,172 (lemah), setelah rotasi diperbesar menjadi 0,730 (kuat), sehingga variabel ini dapat dimasukkan sebagai faktor 4 .

16. Variabel komunikasi antar rekan kerja adalah nilai korelasi variabel komunikasi antar rekan kerja dengan faktor 2 sebelum rotasi adalah 0,417 (lemah), setelah rotasi diperbesar menjadi 0,720 (kuat), sehingga variabel ini dapat dimasukkan sebagai faktor 2 .

17. Variabel komunikasi antar atasan adalah nilai korelasi variabel komunikasi antar atasan dengan faktor 2 sebelum rotasi adalah 0,465 (lemah), setelah rotasi diperbesar menjadi 0,632 (cukup kuat), sehingga variabel ini dapat dimasukkan sebagai faktor 2 .

18. Variabel penempatan sesuai kemampuan adalah nilai korelasi variabel penempatan sesuai kemampuan dengan faktor 2 sebelum rotasi adalah 0,264 (lemah), setelah rotasi diperbesar menjadi 0,595 (cukup kuat), sehingga variabel ini dapat dimasukkan sebagai faktor 2. 


\section{Volume 19 Nomor 2}

19. Variabel pekerjaan yang menantang adalah nilai korelasi variabel pekerjaan yang menantang dengan faktor 2 sebelum rotasi adalah 0,435 (lemah), setelah rotasi diperbesar menjadi 0,581 (cukup kuat), sehingga variabel ini dapat dimasukkan sebagai faktor 2 .

20. Variabel kepemimpinan adalah nilai korelasi variabel kepemimpinan dengan faktor 1 sebelum rotasi adalah 0,377 (lemah), setelah rotasi diperbesar menjadi 0,555 (cukup kuat), sehingga variabel ini dapat dimasukkan sebagai faktor 1 .

21. Variabel rekan kerja adalah nilai korelasi variabel rekan kerja dengan faktor 2 sebelum rotasi adalah -0,525 (lemah), setelah rotasi diperbesar menjadi 0,677 (cukup kuat), sehingga variabel ini dapat dimasukkan sebagai faktor 2.

Berdasarkan uraian tersebut, dapat diringkaskan faktor-faktor yang mempengaruhi kepuasan kerja karyawan pada PT Astra Cabang Medan seperti disajikan pada tabel 10 berikut:

Tabel 10 : Faktor-faktor yang mempengaruhi kepuasan kerja karyawan

\begin{tabular}{|l|l|l|l|}
\hline Atribut & Korelasi & Faktor & Keterangan \\
\hline V11 & 0,776 & 1 & Kebijakan dan prosedur kerja \\
V9 & 0,735 & 1 & Perlakuan adil \\
V1 & 0,648 & 1 & Gaji pokok \\
V10 & 0,632 & Kondisi kerja \\
V13 & 0,534 & 1 & Pujian \\
V20 & 0,555 & 1 & Kepemimpinan \\
\hline V8 & 0,775 & 2 & Promosijabatan \\
V16 & 0,720 & 2 & Komunikasi antar rekan kerja \\
V21 & 0,677 & 2 & Rekan kerja \\
V17 & 0,632 & 2 & Komunikasi antar atasan \\
V18 & 0,595 & 2 & Penempatan sesuai kemampuan \\
V19 & 0,581 & 2 & Pekerjaan yang menantang \\
\hline V6 & 0,717 & 3 & Jamsostek \\
V3 & 0,693 & 3 & Tunjangan keluarga \\
V12 & 0,529 & 3 & Kelompok kerja \\
\hline V15 & 0,730 & 4 & Faktor instrinsik dari pekerjaan \\
V14 & 0,569 & 4 & Tanggungjawab \\
V5 & 0,533 & 4 & Tanda jasa \\
\hline V7 & 0,711 & 5 & Kendaraan dinas \\
V4 & 0,545 & 5 & Biaya pengobatan dan perawatan \\
\hline V2 & 0,879 & & Insentif atau bonus \\
\hline
\end{tabular}

Sumber: Diolah dari Tabel 8

Component Transformation Matrix

Tabel 11. Component Transformation Matrix

\begin{tabular}{|l|l|l|l|l|l|l|}
\hline Component & 1 & 2 & 3 & 4 & 5 & 6 \\
\hline 1 & 0,622 & 0,534 & 0,448 & 0,292 & 0,117 & 0,167 \\
2 & $-0,649$ & 0,712 & 0,124 & $-0,117$ & $-0,163$ & 0,127 \\
3 & $-0,416$ & $-0,355$ & 0,548 & 0,619 & 0,118 & 0,053 \\
4 & $-0,124$ & 0,223 & $-0,352$ & 0,221 & 0,829 & $-0,274$ \\
5 & $-0,053$ & $-0,175$ & 0,209 & $-0,471$ & 0,480 & 0,686 \\
\hline
\end{tabular}

Extraction Method: Principal Component Analysis. Rotation Method: Varimax with Kaiser Normalization.

Dari tabel di atas terlihat bahwa pada diagonal faktor (component) 1 yang berada di atas angka $0,50(0,622)$. Untuk component 2 angka di atas 0,50 (0,534 dan 0,712). Untuk component 3 angka di atas $0,50(0,548)$. Untuk component 4 angka di atas $0,50(0,619)$. Untuk component 5 angka di atas $0,50(0,829)$ dan untuk component 6 angka di atas $0,50(0,686)$ Hal ini yang menunjukkan bahwa enam faktor (component) yang terbentuk sudah tepat, karena mempunyai korelasi tinggi 


\section{Nilai Korelasi Antar Faktor}

Setelah dilakukan rotasi, diketahui nilai korelasi antara faktor 1, faktor 2, faktor 3, faktor 4, faktor 5 dan faktor 6 terhadap kepuasan kerja karyawan, yaitu nilai korelasi faktor pertama sebesar $16,645 \%$, faktor kedua sebesar 14,565\%, faktor ketiga sebesar 10,693\%; faktor keempat sebesar 8,090\%, faktor kelima sebesar 6,539\% dan faktor keenam 6,068\%. Jumlah variansnya sebesar $62,599 \%$, hal ini menunjukkan masih terdapat faktor lain sebagai faktor yang mempengaruhi kepuasan kerja karyawan pada PT Astra Cabang Medan yang belum terungkap sebesar $37,401 \%$. Dengan demikian, kedua puluh satu faktor tersebut dapat menjelaskan kepuasan kerja karyawan sebesar 62,599\%.

\section{Faktor yang Paling Dominan Mempengaruhi Kepuasan Kerja Karyawan}

Faktor yang dominan mempengaruhi kepuasan kerja karyawan pada PT Astra Cabang Medan adalah insentif atau bonus dengan nilai korelasi sebesar 0,879; kebijakan dan prosedur kerja dengan nilai korelasi sebesar 0,776; promosi jabatan dengan nilai korelasi sebesar 0,775; faktor instrinsik dari pekerjaan dengan nilai korelasi sebesar 0,730; faktor jamsostek dengan nilai korelasi sebesar 0,717 dan faktor kendaraan dinas dengan nilai korelasi sebesar 0,711 .

PT Astra Cabang Medan memberikan insentif atau bonus kepada para karyawan yang berhasil menjual mobil diatas standar yang ditetapkan. Estándar kinerja karyawan sebanyak 25 unit per tahun. Besar insentif yang diberikan kepada karyawan sebesar Rp 2.000.000,00/ unit kendaraan. Bagi karyawan bagian bengkel diberikan insentif sebesar Rp $5.000,00 /$ unit kendaraan yang diperbaiki. Insentif atau bonus dibayarkan setiap awal bulan bersamaan dengan pembayaran gaji pokok.

PT Astra Cabang Medan selalu melibatkan karyawan dalam menetapkan kebijakan yang berhubungan dengan pembagian tugas, tanggungjawab dan wewenang masing-masing bagian, termasuk didalamnya kebijakan penentuan besar insentif dan prosedur kerja yang harus dipatuhi dan ditaati oleh karyawan. Keterlibatan karyawan dalam menentukan kebijakan dan prosedur kerja tersebut, dapat meningkatkan kepuasan kerja karyawan, karena mereka lebih mudah memahami dan mengerti setiap kebijakan yang ditetapkan oleh atasan.

PT Astra Cabang Medan memberikan kesempatan kepada karyawan yang berprestasi untuk menduduki jabatan yang lebih tinggi. Hal ini bertujuan untuk meningkatkan kepuasan kerja karyawan. Promosi jabatan dilakukan berdasarkan kinerja karyawan, dimana karyawan yang memiliki kinerja terbaik dibandingkan karyawan lainnya lebih berpeluang untuk menduduki jabatan yang lebih tinggi. Promosi jabatan dilakukan saat terdapat posisi atau jabatan yang lowong.

Faktor instrinsik pekerjaan berkaitan dengan persyaratan keterampilan yang dibutuhkan untuk menyelesaikan suatu pekerjaan tertentu. Untuk meningkatkan keterampilan karyawan, perusahaan memberikan pelatihan kepada karyawan yang tidak mampu menyelesaikan tugas-tugasnya dengan baik. Dengan adanya pelatihan tersebut, diharapkan karyawan dapat menyelesaikan tugas-tugasnya, sehingga kinerjanya meningkat dan pada akhirnya meningkatkan kepuasan kerja.

PT Astra Cabang Medan mengikutsertakan karyawan sebagai peserta Jamsostek untuk memberikan jaminan kesehatan pada saat mereka mengalami kecelakaan kerja. Dengan adanya jamsestek ini, maka karyawan yang jatuh sakit atau mengalami kecelakaan saat melaksanakan tugas, seluruh biaya pengobatan dan perobatan ditanggung oleh asuransi.

PT Astra Cabang Medan memberikan kendaraan dinas kepada para karyawan untuk mendukung penyelesaian tugas-tugas yang dibebankan oleh atasan. Kendaraan dinas tersebut, berupa mobil dan sepeda motor. Tujuan pemberian kendaraan dinas tersebut adalah untuk memudahkan karyawan dalam melaksanakan tugas-tugasnya. 


\section{KESIMPULAN DAN SARAN}

A. Kesimpulan

Berdasarkan hasil penelitian dan pembahasan, terdapat beberapa kesimpulan:

1. Angka KMO Measure of Sampling Adeguacy (MSA) sebesar 0,825 berada di atas 0,50, dengan signifikansi 0,000, maka variabel layak untuk dianalisis lebih lanjut.

2. Scree plot menampakkan grafik, di mana dari faktor 1 ke faktor 2 (garis sumber component number $=1$ ke 2), arah garis menurun tajam. Kemudian dari angka 2 sampai angka 6, arah garis masih menurun dengan slope yang semakin kecil. Faktor ketujuh sampai kedua puluh satu sudah berada di bawah angka dari sumbu Y (eigenvalues). Hal ini menunjukkan bahwa enam faktor paling bagus untuk meringkas kedua puluh satu faktor yang mempengaruhi kepuasan kerja karyawan pada PT. Astra Cabang Medan.

3. Sebelum rotasi, keempat belas variabel yang mempengaruhi kepuasan kerja karyawan tidak jelas termasuk dalam faktor mana, maka dilakukan rotasi. Sesudah rotasi, keempat belas variabel yang dianalisis sudah jelas masuk ke dalam faktor mana.

4. Faktor yang dominan mempengaruhi kepuasan kerja karyawan PT Astra Cabang Medan adalah insentif atau bonus, kebijakan dan prosedur kerja, promosi jabatan, instrinsik dari pekerjaan, jamsostek dan kendaraan dinas. Faktor yang paling dominan mempengaruhi kepuasan kerja karyawan adalah insentif atau bonus.

\section{B. Saran}

Berdasarkan hasil penelitian dan pembahasan ada beberapa saran yaitu:

1. Untuk meningkatkan kepuasan kerja karyawan, sebaiknya perusahaan menambah besar insentif atau bonus, memperhatikan penetapan kebijakan dan prosedur kerja, mempertahankan pemberian jamsostek dan kendaraan dinas.

2. Sebaiknya perusahaan memberikan peluang yang paling besar kepada karyawan yang berprestasi terbaik untuk dipromosikan ke jabatan yang lebih tinggi.

\section{DAFTAR PUSTAKA}

Gomes, Faustino Cardoso. 2010. Manajemen Sumber Daya Manusia, Edisi Pertama, Yogyakarta: Andi.

Handoko, T. Hani, 2002. Manajemen Personalia dan Sumber Daya Manusia. Yogyakarta: BPFE-UGM.

Hair, Joseph F. Jr., Rolph E. Anderson, Ronald L. Tatham, \& William Black. 2000, Multivariate Data Analysis With Readings. New Jersey: Prentice- Hall, Inc.

Hasibuan, Malayu, S.P., 2003. Manajemen Sumber Daya Manusia, Edisi Revisi, Jakarta: Bumi Aksara.

Kurniasih, 2005. Faktor-faktor yang Mempengaruhi Kepuasan Kerja Karyawan Pada PT. Megah Rubber Factory Semarang, Skripsi: STIE Stikubank, Semarang.

Rivai, Veithzal, 2004. Manajemen Sumber Daya Manusia, Edisi Pertama, Jakarta: Salemba Empat.

Santono, Singgih dan Tjiptono, Fandy, 2001. Riset Pemasaran: Konsep dan Aplikasi dengan SPSS, Jakarta: Alex Media Komputindo. 
Volume 19 Nomor 2

Sitohang, A. 2007. Manajemen Sumber Daya Manusia: Suatu Pendekatan Mikro, Cetakan Ketiga, Jakarta: Pradnya Paramida.

Sugiyono, 2005. Metode Penelitian Administrasi, Bandung: Alfabeta.

Sutrisno, Edy, 2009. Manajemen Sumber Daya Manusia, Jakarta: Kencana Prenada Media Group.

Yulinda1 dan Sri Wulan Harlyanti, 2009. Faktor-faktor yang mempengaruhi kepuasan kerja pegawai pada pegawai Dinas Luar Asuransi Jiwa Bersama Bumiputera 1912 Cabang Setiabudi Medan. Jurnal Manajemen Bisnis, Volume 2, Nomor 1 Januari 2009. Medan: USU.

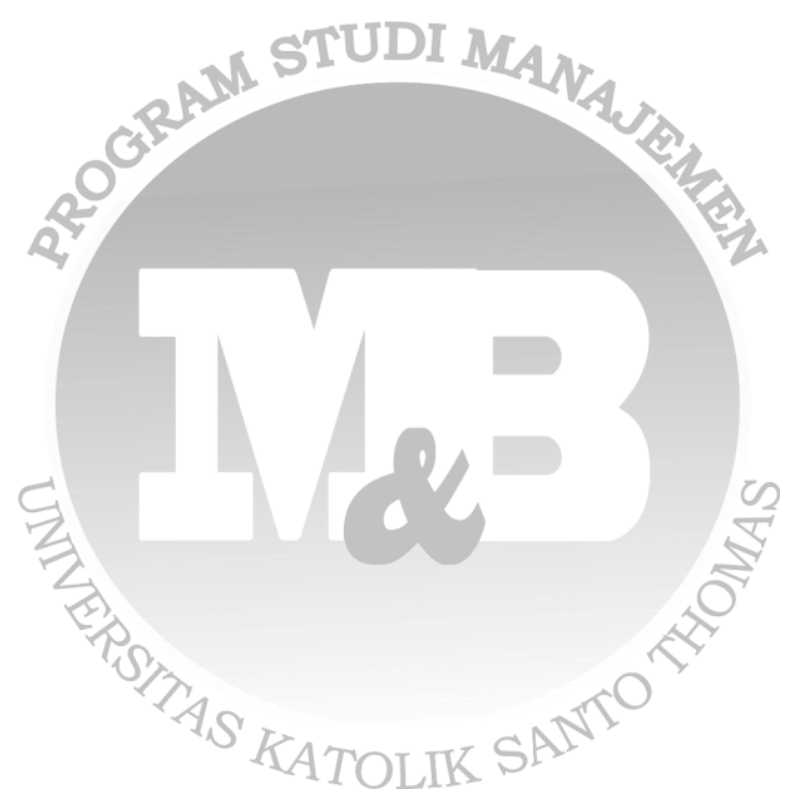

